\author{
P. An - M. Teran-Garcia $\cdot$ T. Rice $\cdot$ T. Rankinen $\cdot$ \\ S. J. Weisnagel · R. N. Bergman • R. C. Boston • \\ S. Mandel · D. Stefanovski · A. S. Leon · J. S. Skinner • \\ D. C. Rao $\cdot$ C. Bouchard
}

\title{
Genome-wide linkage scans for prediabetes phenotypes in response to 20 weeks of endurance exercise training in non-diabetic whites and blacks: the HERITAGE Family Study
}

Received: 7 October 2004 / Accepted: 27 January 2005 / Published online: 3 May 2005

(C) Springer-Verlag 2005

\begin{abstract}
Aims/hypothesis: Impaired insulin secretion, insulin action, insulin-independent glucose effectiveness, glu-
\end{abstract}

P. An $(\bowtie) \cdot$ T. Rice $\cdot$ S. Mandel $\cdot$ D. C. Rao

Division of Biostatistics,

Washington University School of Medicine, Campus Box 8067, 660 South Euclid Avenue,

St Louis, MO 63110, USA

e-mail: anping@wustl.edu

Tel.: +1-314-3623614

Fax: +1-314-3622693

M. Teran-Garcia $\cdot$ T. Rankinen $\cdot$ C. Bouchard

Pennington Biomedical Research Center,

Louisiana State University,

Baton Rouge, LA, USA

S. J. Weisnagel

Department of Social and Preventive Medicine

and Laval University Health Center,

Laval University,

Ste-Foy, QC, Canada

R. N. Bergman

Department of Physiology and Biophysics,

USC Diabetes Research Center,

Keck-USC School of Medicine,

University of Southern California,

Los Angeles, CA, USA

R. C. Boston · D. Stefanovski

School of Veterinary Medicine,

University of Pennsylvania,

Kennett Square, PA, USA

A. S. Leon

Division of Kinesiology,

University of Minnesota,

Minneapolis, MN, USA

\section{J. S. Skinner}

Department of Kinesiology, Indiana University, Bloomington, IN, USA

D. C. Rao

Departments of Genetics and Psychiatry,

Washington University School of Medicine,

St Louis, MO, USA cose tolerance and the associated abnormalities in insulin and glucose metabolism phenotypes are precursors of type 2 diabetes. Genome-wide multipoint variance component linkage scans were carried out using 654 markers to identify quantitative trait loci for insulin sensitivity, acute insulin response to glucose, disposition index and glucose effectiveness training responses in whites and blacks in the HERITAGE Family Study. Methods: These phenotypes were obtained from an IVGTT with the minimal model. The distributions of insulin sensitivity, acute insulin response to glucose and disposition index training responses (posttraining minus baseline) were approximately normalised using a square-root transformation. All phenotypes were adjusted for the effects of age, BMI and their respective baseline values within sex and generation by race prior to linkage scans. Results: In blacks, a promising linkage with a maximum lod score of 3.1 on $19 \mathrm{q}(54-62 \mathrm{Mb})$ for glucose effectiveness training response was found. Six interesting linkages with lod scores of at least 1.0 were found for disposition index training response in whites. They included 1p (30 Mb), 3q (152 Mb), 6p (23-42 Mb), 7q (95-96 $\mathrm{Mb}), 10 \mathrm{p}(15 \mathrm{Mb})$ and $12 \mathrm{q}(119-126 \mathrm{Mb})$. Conclusions/ interpretation: Quantitative trait loci for 20 weeks of endurance exercise training responses in insulin action and glucose metabolism phenotypes were found on chromosome $19 q$ as well as $6 p$ and $7 q$, with nominal $(6 p, 7 q)$ but consistent (6p) linkages across the races.

Keywords Acute insulin response to glucose $\cdot$ Disposition index $\cdot$ Exercise training response $\cdot$ Glucose effectiveness Insulin sensitivity · IVGTT · Minimal model · Quantitative trait loci

Abbreviations $\quad \mathrm{AIR}_{\mathrm{g}}$ : acute insulin response to glucose DI: disposition index - GYS1: glycogen synthase 1 gene · LDB: location database - PPAR: peroxisome proliferatoractivated receptor $\cdot S_{\mathrm{I}}$ : insulin sensitivity $\cdot S_{\mathrm{G}}$ : glucose effectiveness 


\section{Introduction}

Type 2 diabetes is characterised by an elevation in blood glucose in the fasting state and/or following a glucose challenge resulting from insulin resistance and insufficient compensatory insulin secretion by pancreatic beta islet cells. Insulin action, as the insulin sensitivity index $\left(S_{\mathrm{I}}\right)$, can be estimated from the frequently sampled IVGTT with minimal model. Other indices include the acute insulin response to glucose $\left(\mathrm{AIR}_{\mathrm{g}}\right.$, reflecting insulin secretion) and the disposition index $\left(\mathrm{DI}=S_{\mathrm{I}} \times \mathrm{AIR}_{\mathrm{g}}\right.$, measuring overall glucose homeostasis and taking account of the hyperbolic relationship between $S_{\mathrm{I}}$ and insulin secretion). Glucose effectiveness $\left(S_{\mathrm{G}}\right)$ represents an insulin-independent effect whereby glucose mediates its own disposal from plasma. Impairments in these insulin action and glucose metabolism indices are recognised as prediabetic phenotypes involving pathogenic development and pathogenetic processes of type 2 diabetes. Exercise training improves peripheral $S_{\mathrm{I}}$ and $S_{\mathrm{G}}$ in healthy human subjects [1], and significant improvements in $S_{\mathrm{I}}$, $\mathrm{AIR}_{\mathrm{g}}$, DI and $S_{\mathrm{G}}$ in response to 20 weeks of endurance exercise training have been observed and reported in the HERITAGE Family Study [2]. Recent investigations in HERITAGE provide further evidence that physiological training responses vary appreciably from person to person, and these individual differences are influenced by genetic factors [3].

Genome-wide linkage scans localising quantitative trait loci for type 2 diabetes and associated traits are numerous. However, there are no scans for such unique traits of glucose and insulin metabolism phenotypes in response to endurance exercise training, except for the baseline values [4] and fasting values [5] in HERITAGE. In this study, $S_{\mathrm{I}}$, AIR $_{\mathrm{g}}$, DI and $S_{\mathrm{G}}$ derived from an IVGTT using the Minimal Model Millennium software [6] were obtained before and after 20 weeks of endurance exercise training. Training responses were defined as differences between post-training and baseline values.

We searched for quantitative trait loci that may harbour candidate genes influencing changes in $S_{\mathrm{I}}, \mathrm{AIR}, \mathrm{g}$, and $S_{\mathrm{G}}$ in response to endurance exercise training in sedentary and non-diabetic whites and blacks.

\section{Subjects, materials and methods}

HERITAGE was designed to investigate the role of the genotype in cardiovascular, metabolic and hormonal responses to aerobic exercise training, and the contribution of exercise training to changes in type 2 diabetes and cardiovascular disease risk factors. In general, subjects in the 20week training programme were required to be in good health. All subjects had been sedentary at baseline for at least 6 months prior to study entry [7]. Age was $\leq 65$ years for parents and $\geq 17$ years for offspring. Subjects with uncontrolled endocrine and metabolic disorders or diabetes were excluded from participation. Resting blood pressure was $\leq 159 / 99 \mathrm{~mm} \mathrm{Hg}$. None of the subjects took medications to control hypertension or for dyslipidaemia. BMI had to be less than $40 \mathrm{~kg} / \mathrm{m}^{2}$. However, several subjects with their BMI slightly higher than $40 \mathrm{~kg} / \mathrm{m}^{2}$ were approved for participation by supervising physicians, because they were considered to be in good health and able to exercise. HERITAGE design, protocol, population, inclusion and exclusion criteria are described elsewhere [7].

A total of 441 subjects from 98 white families and 187 subjects from 90 black families had complete data. Sample size descriptions are given in Table 1 for whites and Table 2 for blacks. The Institutional Review Boards at five participating centres of HERITAGE approved the study protocol. Written informed consent was obtained from each participant.

The training programme has been described elsewhere [8]. Each subject was administered a comprehensive battery of tests prior to the 20-week training programme, including an IVGTT. Subjects then completed 60 sessions of endurance exercise on cycle ergometers that were computercontrolled to maintain the subjects' heart rates at levels associated with fixed percentages of their baseline maximal oxygen uptake. The full test battery, including the IVGTT, was administered again after completion of the training programme. The IVGTT protocol [9] has been detailed previously [4]. It was performed in the morning after overnight fasting for $12 \mathrm{~h}$. Blood samples to measure plasma glucose and insulin were taken $1,3,5,10,15,20,30,45,60,75,90$,

Table 1 Basic characteristics of whites

\begin{tabular}{|c|c|c|c|c|c|c|}
\hline Variable $^{\mathrm{a}}$ & $\begin{array}{l}\text { Number } \\
\text { Fathers }\end{array}$ & Mean & SD & $\begin{array}{l}\text { Number } \\
\text { Mothers }\end{array}$ & Mean & $\mathrm{SD}$ \\
\hline Age (years) & 89 & $53.5^{\mathrm{b}}$ & 5.3 & 76 & $52.2^{\mathrm{b}}$ & 5.2 \\
\hline BMI $\left(\mathrm{kg} / \mathrm{m}^{2}\right)$ & 89 & $28.3^{\mathrm{b}}$ & 4.5 & 76 & $27.5^{\mathrm{b}}$ & 4.9 \\
\hline Baseline $S_{\mathrm{I}}$ & 89 & $3.24^{\mathrm{b}, \mathrm{c}}$ & 3.09 & 75 & $4.90^{\mathrm{c}}$ & 3.26 \\
\hline Response $S_{\mathrm{I}}$ & 89 & 0.27 & 2.64 & 74 & -0.17 & 2.56 \\
\hline Baseline $\mathrm{AIR}_{\mathrm{g}}$ & 89 & $654^{\mathrm{c}}$ & 569 & 76 & $496^{\mathrm{b}, \mathrm{c}}$ & 324 \\
\hline Response $\mathrm{AIR}_{\mathrm{g}}$ & 89 & -59 & 343 & 76 & -19 & 153 \\
\hline Baseline DI & 89 & $1,679^{\mathrm{b}, \mathrm{c}}$ & 1,586 & 75 & $2,213^{\mathrm{c}}$ & 1,781 \\
\hline Response DI & 89 & 82 & 1,361 & 74 & -186 & 1,277 \\
\hline Baseline $S_{\mathrm{G}}$ & 89 & 1.45 & 0.66 & 76 & 1.61 & 0.89 \\
\hline Response $S_{\mathrm{G}}$ & 89 & $0.10^{\mathrm{b}}$ & 0.86 & 76 & -0.04 & 0.89 \\
\hline Variable & Sons & & & Daughter & & \\
\hline Age (years) & 138 & $25.5^{\mathrm{b}}$ & 6.2 & 138 & $25.6^{\mathrm{b}}$ & 6.3 \\
\hline BMI $\left(\mathrm{kg} / \mathrm{m}^{2}\right)$ & 138 & $25.8^{\mathrm{b}, \mathrm{c}}$ & 4.9 & 138 & $23.8^{\mathrm{b}, \mathrm{c}}$ & 4.5 \\
\hline Baseline $S_{\mathrm{I}}$ & 138 & $4.36^{\mathrm{b}}$ & 2.57 & 135 & 4.69 & 2.86 \\
\hline Response $S_{\mathrm{I}}$ & 136 & 0.61 & 2.73 & 135 & 0.12 & 2.70 \\
\hline Baseline $\mathrm{AIR}_{\mathrm{g}}$ & 138 & $785^{\mathrm{b}}$ & 630 & 138 & $630^{\mathrm{b}, \mathrm{c}}$ & 432 \\
\hline Response $\mathrm{AIR}_{\mathrm{g}}$ & 138 & -58 & 355 & 138 & -13 & 249 \\
\hline Baseline DI & 138 & $2,618^{\mathrm{b}}$ & 1,738 & 135 & 2,514 & 1,615 \\
\hline Response DI & 136 & 328 & 2,026 & 135 & 71 & 1,760 \\
\hline Baseline $S_{\mathrm{G}}$ & 138 & 1.60 & 0.87 & 138 & 1.78 & 0.90 \\
\hline Response $S_{\mathrm{G}}$ & 138 & $0.35^{\mathrm{b}}$ & 1.19 & 138 & 0.13 & 1.27 \\
\hline
\end{tabular}

${ }^{\mathrm{a}}$ Units: $S_{\mathrm{I}}, 10^{-4} \mathrm{~min}^{-1} / \mu \mathrm{U} / \mathrm{ml} ; \mathrm{AIR}_{\mathrm{g}}, \mathrm{pmol} / 1 \times 10 \mathrm{~min} ; S_{\mathrm{G}}, 100 \mathrm{~min}^{-1}$ ${ }^{\mathrm{b}}$ Differences in means are significant $(p<0.05)$ for father-son or mother-daughter comparisons

${ }^{c}$ Differences in means are significant $(p<0.05)$ for spouse or sibling comparisons 
Table 2 Basic characteristics of blacks

\begin{tabular}{|c|c|c|c|c|c|c|}
\hline Variable $^{\mathrm{a}}$ & $\begin{array}{l}\text { Number } \\
\text { Fathers }\end{array}$ & Mean & $\mathrm{SD}$ & $\begin{array}{l}\text { Number } \\
\text { Mothers }\end{array}$ & Mean & SD \\
\hline Age (years) & 17 & $49.2^{\mathrm{b}, \mathrm{c}}$ & 7.8 & 30 & $45.9^{\mathrm{b}, \mathrm{c}}$ & 6.1 \\
\hline BMI $\left(\mathrm{kg} / \mathrm{m}^{2}\right)$ & 17 & 26.8 & 4.6 & 30 & 29.4 & 5.3 \\
\hline Baseline $S_{\mathrm{I}}$ & 16 & 2.74 & 3.38 & 30 & 2.98 & 2.84 \\
\hline Response $S_{\mathrm{I}}$ & 16 & 0.11 & 2.31 & 30 & 0.12 & 2.70 \\
\hline Baseline $\mathrm{AIR}_{\mathrm{g}}$ & 17 & $706^{\mathrm{b}, \mathrm{c}}$ & 452 & 30 & $1,595^{\mathrm{b}}$ & 2,164 \\
\hline Response $\mathrm{AIR}_{\mathrm{g}}$ & 17 & 6 & 385 & 30 & -150 & 626 \\
\hline Baseline DI & 16 & 2,052 & 3,232 & 30 & 3,469 & 4,312 \\
\hline Response DI & 16 & -172 & 2,452 & 30 & 504 & 3,834 \\
\hline Baseline $S_{\mathrm{G}}$ & 17 & $1.66^{\mathrm{c}}$ & 1.14 & 30 & 1.85 & 1.05 \\
\hline Response $S_{\mathrm{G}}$ & 17 & -0.09 & 0.99 & 30 & 0.17 & 1.52 \\
\hline Variable & Sons & & & Dau & & \\
\hline Age (years) & 59 & $28.6^{\mathrm{c}}$ & 6.7 & 81 & $27.8^{\mathrm{c}}$ & 8.1 \\
\hline BMI $\left(\mathrm{kg} / \mathrm{m}^{2}\right)$ & 59 & 27.5 & 5.2 & 81 & 27.8 & 6.4 \\
\hline Baseline $S_{\mathrm{I}}$ & 59 & 2.63 & 1.86 & 81 & 2.77 & 2.15 \\
\hline Response $S_{\mathrm{I}}$ & 57 & 0.59 & 1.79 & 81 & 0.32 & 2.01 \\
\hline Baseline $\mathrm{AIR}_{\mathrm{g}}$ & 59 & $1,743^{\mathrm{c}}$ & 1,443 & 81 & 1,813 & 1,376 \\
\hline Response $\mathrm{AIR}_{\mathrm{g}}$ & 59 & -163 & 700 & 81 & -37 & 505 \\
\hline Baseline DI & 59 & 3,569 & 3,083 & 81 & 4,002 & 3,209 \\
\hline Response DI & 57 & 388 & 3,046 & 81 & 456 & 3,004 \\
\hline Baseline $S_{\mathrm{G}}$ & 59 & $1.94^{\mathrm{c}}$ & 1.14 & 81 & 2.15 & 1.28 \\
\hline Response $S_{\mathrm{G}}$ & 59 & 0.32 & 1.79 & 81 & 0.32 & 1.57 \\
\hline
\end{tabular}

${ }^{\mathrm{a}}$ Units: $S_{\mathrm{I}}, 10^{-4} \mathrm{~min}^{-1} / \mu \mathrm{U} / \mathrm{ml} ; \mathrm{AIR}_{\mathrm{g}}, \mathrm{pmol} / 1 \times 10 \mathrm{~min} ; S_{\mathrm{G}}, 100 \mathrm{~min}^{-1}$

${ }^{\mathrm{b}}$ Differences in means are significant $(p<0.05)$ for spouse or sibling comparisons

${ }^{c}$ Differences in means are significant $(p<0.05)$ for father-son or mother-daughter comparisons

120,150 and 180 min after the end of the glucose injection in the opposite arm.

Plasma insulin was measured by radioimmunoassay after polyethylene glycol separation [10]. Polyclonal antibodies that cross-react more than $90 \%$ with proinsulin, and presumably its conversion intermediates, were used [11, 12]. The intra- and interassay coefficients of variation were 7.7 and $10.3 \%$, respectively. Plasma glucose was enzymatically determined using a reagent kit distributed by Diagnostic Chemicals (Oxford, CT, USA). AIR $\mathrm{g}$ was computed as the incremental integrated area under the insulin curve for the first $10 \mathrm{~min}$ of the IVGTT. $S_{\mathrm{I}}, \mathrm{AIR}_{\mathrm{g}}$, DI and $S_{\mathrm{G}}$ were all derived from the Minimal Model Millennium software [6].

$S_{\mathrm{I}}, \mathrm{AIR}_{\mathrm{g}}$ and DI exercise training responses were skewed and were approximately normalised using a square-root transformation. $S_{\mathrm{I}}, \mathrm{AIR}_{\mathrm{g}}$, DI and $S_{\mathrm{G}}$ exercise training responses were adjusted for the effects of age, age ${ }^{2}, a g e^{3}$, $\mathrm{BMI}$ and their respective baseline values (to assess genetic determinants on these exercise training response phenotypes independently of the effects of their baseline levels) within each of the sex by generation groups, separately by race, in both the mean and the variance using a stepwise multiple regression procedure. For each of the regressions, only terms that were significant at the $5 \%$ level were retained. Finally, each of the adjusted variables was standardised (mean of $0, \mathrm{SD}$ of 1 ) within $\mathrm{sex} \times$ generation groups, separately by race.
PCR conditions and genotyping methods have been described previously [13]. Incompatibilities of Mendelian inheritance were checked, and markers showing incompatibilities (between 5 and $10 \%$ depending on marker) were retyped completely from PCR reaction to the genotyping. Microsatellite markers were mainly selected from the Marshfield panel version 8a (http://www.marshfieldclinic. org/geneticsresearch). Map locations in location database (LDB) composite units were derived from the Location Database of Southampton, UK (http://www.cedar.genetics. soton.ac.uk/public html). The LDB units were obtained by integrating different types of data (genetic linkage maps, radiation hybrid maps, physical maps, cytogenetic data, and mouse homology) into a single map. The data were obtained from the Internet, published sources, and the Wessex Human Genetics Institute. Here, LDB units were used to perform linkage scans, and the physical distance in $\mathrm{Mb}$, obtained from the National Center for Biotechnology Information physical map, build 34.3, was used to present scan results.

Multipoint linkage analyses were performed using the variance components model as implemented in the computer program SEGPATH $[14,15]$. Under this model, a phenotype is under the influence of the additive effects of a trait locus $(g)$, a residual familial background modelled as a pseudopolygenic component $\left(G_{\mathrm{R}}\right)$, and a residual nonfamilial component $(r)$. The effects of the trait locus and the pseudopolygenic component on the genotype are quantified by the heritabilities $h_{\mathrm{g}}^{2}$ and $h_{\mathrm{r}}{ }^{2}$ respectively. Allele-sharing probabilities at each marker location for each sib pair were estimated using the multipoint approach in the computer program MAPMAKER/SIBS [16], and were entered into the SEGPATH model. Other parameters in the model include spouse resemblance $(u)$, additional sibling resemblance $(b)$ and the phenotype means and variances. The linkage hypothesis is tested by restricting $h_{\mathrm{g}}{ }^{2}=0$. A likelihood ratio test contrasting the null versus the alternative hypotheses is asymptotically distributed as a 50:50 mixture of a $\chi^{2}$ with 1 degree of freedom and a point mass at zero [17]. The lod score is computed as $\chi^{2} /\left(2 \times \log _{\mathrm{e}} 10\right)$.

\section{Results}

Means and SD for $S_{\mathrm{I}}, \mathrm{AIR}, \mathrm{g}$, DI and $S_{\mathrm{G}}$ exercise training responses, together with the baseline values, separately by sex and generation groups, are presented in Table 1 for whites and Table 2 for blacks. Favourable and significant $(p<0.05)$ exercise training responses have been observed in both races and have been reported elsewhere [2]. Significant $(p<0.05)$ racial differences in means of the exercise training response phenotypes were not found within each of the $s e x \times$ generation groups.

In general, age accounted for little variance in the exercise training responses $\left(<10 \%\right.$ in DI [white sons], $\mathrm{AIR}_{\mathrm{g}}$ [black daughters] and $S_{\mathrm{G}}$ [black mothers]). In contrast, the baseline values were significant predictors of the exercise training responses in both races for most groups, accounting for $20-50 \%$ of the variance (except baseline $\mathrm{AIR}_{\mathrm{g}}$ in 
Table 3 Summary of multipoint linkage scan results with lod scores $\geq 1.0$ in whites and blacks
* Genome-wide false discovery rate or empirical $p$ value is 0.05 at this locus, and empirical $p$ values at the remaining marker sites are non-significant (i.e. empirical $p$ values $>0.05$ )

\begin{tabular}{|c|c|c|c|c|}
\hline Phenotype & Chromosome & Marker & Distance $(\mathrm{Mb})$ & Lod score \\
\hline \multicolumn{5}{|l|}{ Whites } \\
\hline DI & 1p35.1 & D1S1622 & 29.813 & 1.2 \\
\hline DI & $3 \mathrm{q} 25.2$ & D3S1279 & 152.346 & 1.2 \\
\hline DI & $6 \mathrm{p} 22.1$ & D6S1660 & 23.422 & 1.1 \\
\hline DI & $6 \mathrm{p} 22.1$ & D6S299 & 24.033 & 1.2 \\
\hline DI & $6 \mathrm{p} 21.31$ & TNF & 31.647 & 1.1 \\
\hline DI & $6 \mathrm{p} 21.1$ & D6S1017 & 41.724 & 1.0 \\
\hline DI & $7 q 21.3$ & PON1-D7S821 & $94.549-95.670$ & $1.2-1.4$ \\
\hline DI & $10 \mathrm{p} 13$ & D10S191 & 14.564 & 1.1 \\
\hline DI & $12 \mathrm{q} 24.31$ & D12S395 & 118.600 & 1.0 \\
\hline DI & $12 \mathrm{q} 24.33$ & D12S2078 & 126.314 & 1.1 \\
\hline \multicolumn{5}{|l|}{ Blacks } \\
\hline$S_{\mathrm{G}}$ & $1 \mathrm{p} 31.2$ & D1S476 & 57.609 & 1.1 \\
\hline$S_{\mathrm{G}}$ & $1 \mathrm{q} 44$ & D1S304-D1S2682 & $238.330-245.028$ & $1.1-1.7$ \\
\hline$S_{\mathrm{G}}$ & 2p22.1-p21 & D2S2247-D2S2374 & $27.278-35.684$ & $1.3-1.5$ \\
\hline DI & $6 \mathrm{p} 22.1$ & D6S2239 & 26.182 & 1.0 \\
\hline$S_{\mathrm{G}}$ & $10 \mathrm{p} 12.33$ & D10S197 & 26.531 & 1.0 \\
\hline$S_{\mathrm{G}}$ & $10 \mathrm{q} 23.1-\mathrm{q} 23.2$ & D10S541-D10S2470 & $89.656-92.029$ & $1.0-1.4$ \\
\hline$S_{\mathrm{G}}$ & $12 \mathrm{q} 13.11-\mathrm{q} 13.13$ & D12S1661-D12S1604 & $46.893-52.014$ & $1.0-1.3$ \\
\hline DI & $13 q 14.3$ & D13S788 & 49.691 & 1.0 \\
\hline $\mathrm{AIR}_{\mathrm{g}}$ & $15 q 15.3$ & D15S117 & 56.196 & 1.0 \\
\hline$S_{\mathrm{G}}$ & $15 \mathrm{q} 26.2$ & IGF1R & 96.927 & 1.0 \\
\hline $\mathrm{AIR}_{\mathrm{g}}$ & $18 \mathrm{q} 12.3$ & D18S535 & 36.401 & 1.1 \\
\hline$S_{\mathrm{G}}$ & $19 q 13.33-q 13.43$ & GYS1-D19S254 & $54.164-62.359$ & $1.8-3.1^{*}$ \\
\hline$S_{\text {I }}$ & $20 \mathrm{q} 13.12$ & D20S43-D20S481 & $42.885-44.454$ & $1.0-1.1$ \\
\hline$S_{\text {I }}$ & $22 \mathrm{q} 11.23-\mathrm{q} 12.3$ & D22S264-D22S421 & $19.098-24.277$ & $1.0-1.1$ \\
\hline
\end{tabular}

white mothers and black men). After transformation and adjustment of the data, both skewness $(0.34-0.66)$ and kurtosis $(-0.10$ to 1.20$)$ for all the exercise training response phenotypes across races became acceptable.

The mean $( \pm$ SD) heterozygosities for 654 markers used in this study were $0.72 \pm 0.15$ in whites and $0.76 \pm 0.16$ in blacks, with an average intermarker spacing of $2.6 \mathrm{Mb}$. Residual genetic heritabilities for all the four training response phenotypes, as expected in dissecting other complex traits, were modest to moderate, the estimates ranging from $10 \%$ in whites to $20-30 \%$ in blacks. All linkage results with lod scores $\geq 1.0$ are summarised in Table 3 . They include cytogenetic regions of 1p, 1q, 2p, 3q, 6p, 7q, 10p, 10q, 12q, $13 \mathrm{q}, 15 \mathrm{q}, 18 \mathrm{q}, 19 \mathrm{q}, 20 \mathrm{q}$ and 22q. All autosomal linkage scan results are presented for whites in Fig. 1a and for blacks in Fig. 1b. In addition, linkage analysis results on chromosome 6 are depicted in Fig. 2a for whites and Fig. 2b for blacks; those on chromosome 7 are depicted in Fig. 3a for whites and those on chromosome 19 are depicted in Fig. $3 b$ for blacks. The strongest linkage is on $19 q(54-62$ $\mathrm{Mb}$ ) for $S_{\mathrm{G}}$ exercise training response in blacks with promising lod scores $\geq 1.75$ [18] at four markers. These markers include the human skeletal muscle glycogen synthase (GYS1) gene locus (54 Mb, lod score 1.8), D19S601 (57 $\mathrm{Mb}$, lod score 2.1), D19S589 (58 Mb, lod score 2.0) and D19S254 (62 Mb, lod score 3.1).

\section{Discussion}

The strongest linkage evidence was found on $19 \mathrm{q} 13$ in the GYS1 gene locus to D19S254 (54-62 Mb) for $S_{\mathrm{G}}$ exercise training response in blacks (but not in whites), with a maximum lod score of 3.1. HERITAGE and several other studies previously reported linkages in this region for type 2 diabetes and associated risk factors. At D19S589 (58 Mb, lod score 2.0, for $S_{\mathrm{G}}$ exercise training response), there are at least four findings in the literature that are in agreement. They include linkages for a principal component score (lod score 2.1 , primarily percentage body fat, plasma HDL cholesterol and triglycerides) and for fasting insulin (lod score 1.6), both in HERITAGE whites [5, 19], for familial combined hyperlipidaemia in Dutch families (lod score 1.3) [20], and for 2-h glucose in Pima Indians (lod score 1.1) [21]. Moreover, linkages in this region have also been reported in the Framingham Offspring Study (D19S178, 49 $\mathrm{Mb}$, lod score 1.8) for 2-h insulin, in Finnish families (D19S412-D19S867, 52-55 Mb, highest lod score 2.8) for an empirical insulin-resistance index and in multiplex familial type 2 diabetes families (D19S178; GSY1 gene locus, 49-54 Mb, highest lod score 3.2) for plasma triglycerides [22-24]. Recently, two groups reported linkages at this region for type 2 diabetes, one in a subset of the Japanese population with age at diagnosis younger than 45 years 

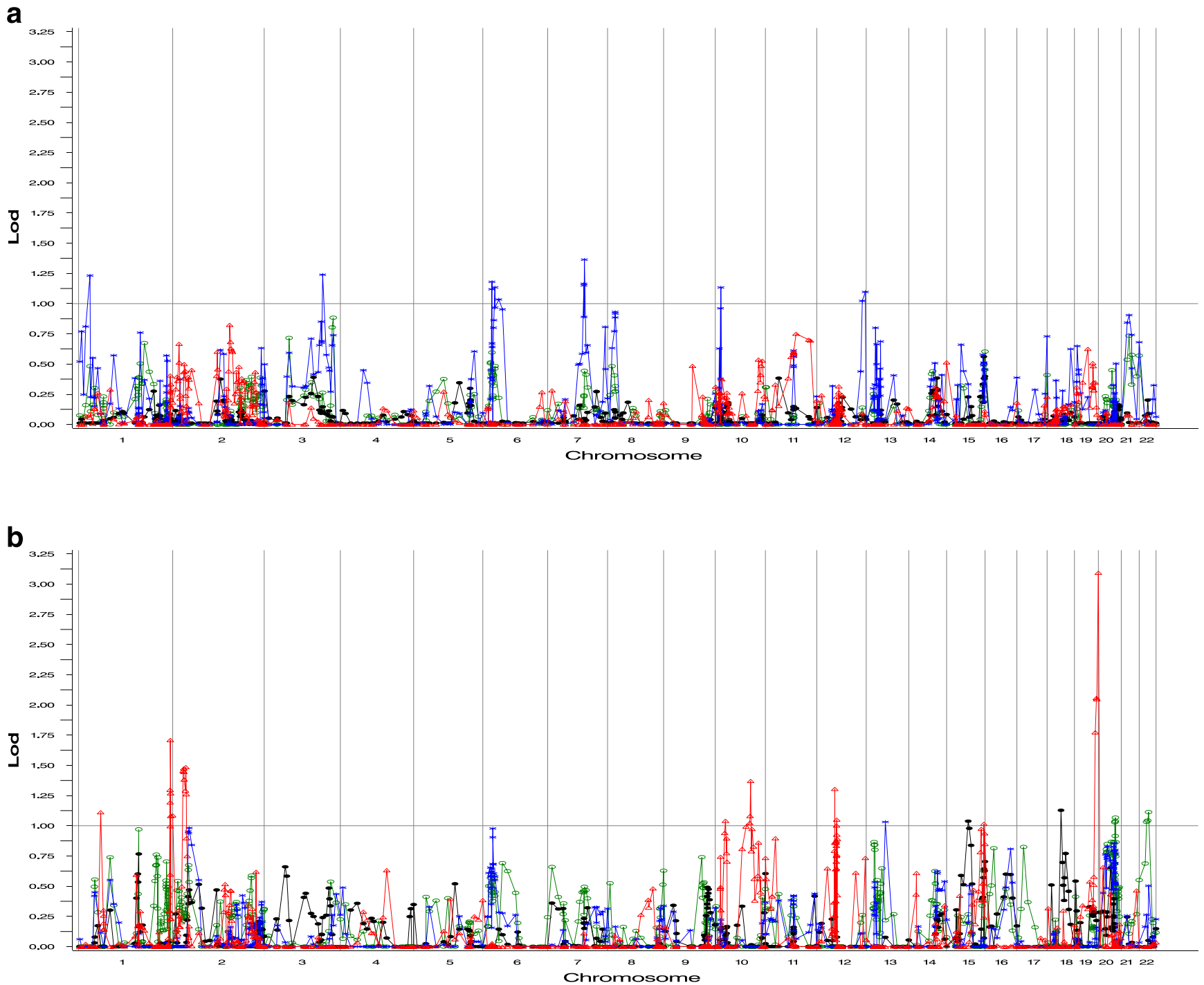

Fig. 1 Multipoint linkage scan results on all autosomes for $S_{\mathrm{I}}$ (green circles), $\mathrm{AIR}_{\mathrm{g}}$ (black dots), DI (blue stars) and $S_{\mathrm{G}}($ red triangles) exercise training responses among whites (a) and blacks (b). Lod score of horizontal reference line is 1.0 for interesting linkages

(D19S571, $58 \mathrm{Mb}$, lod score 1.7), and the other one in a Dutch population (D19S246-D19S601, 56-57 Mb, highest lod score 1.3) $[25,26]$. Follow-up studies on $19 \mathrm{q} 13$ to search for type 2 diabetes susceptibility genes or genes linked to glucose-insulin-lipid metabolism, particularly in response to endurance exercise training, are strongly justified.

$S_{\mathrm{G}}$ represents the ability of glucose itself to mediate its own disposal from plasma, independently from the dynamic changes due to basal insulin. It involves both the autoregulatory effect of hepatic glucose output and peripheral glucose utilisation. Although $S_{\mathrm{G}}$ is different from $S_{\mathrm{I}}$, it is also important in the assessment of glucose tolerance [27]. Decreased $S_{\mathrm{G}}$ levels may predict the development of type 2 diabetes; controversially, others [28] found an opposite association of increased $S_{\mathrm{G}}$ levels with type 2 diabetes using 20 normoglycaemic first-degree relatives of type 2 diabetes patients against 20 matched controls. The storage of glucose as glycogen in human skeletal muscles is frequently impaired in patients with type 2 diabetes and their non-diabetic relatives, partially because of impaired activation of the GYS1 gene by insulin [29]. The GYS1 gene, here linked with $S_{\mathrm{G}}$ exercise training response, encodes glycogen synthase, a key enzyme in glucose storage. GYS1 associations with type 2 diabetes and insulin resistance have been suggested [30] but not confirmed [31] Insulin stimulates GYS1 mRNA expression, and impaired stimulation of GYS1 gene expression by insulin in type 2 diabetes is thought to be secondary to chronic hyperglycaemia [32]. Exercise of large muscle masses is one of the most efficacious modes to prevent the development of insulin resistance by reducing skeletal muscle stores of glycogen and triglycerides [33]. Studies designed to clarify the effects of sequence variation in the GYSI gene on $S_{\mathrm{G}}$ exercise training response are practicable. Finally, and cautiously, given that $S_{\mathrm{I}}$ is associated insulin activation of muscle GYS1 activity, the fact that our linkage finding at the GYS1 gene locus for $S_{\mathrm{G}}$ but not for $S_{\mathrm{I}}$ in blacks but not in whites 
Fig. 2 Multipoint linkage analysis results on chromosome 6 for $S_{\mathrm{I}}$ (circles), $\mathrm{AIR}_{\mathrm{g}}$ (dots), DI (stars) and $S_{\mathrm{G}}$ (triangles) exercise training responses in whites (a) and blacks (b) a
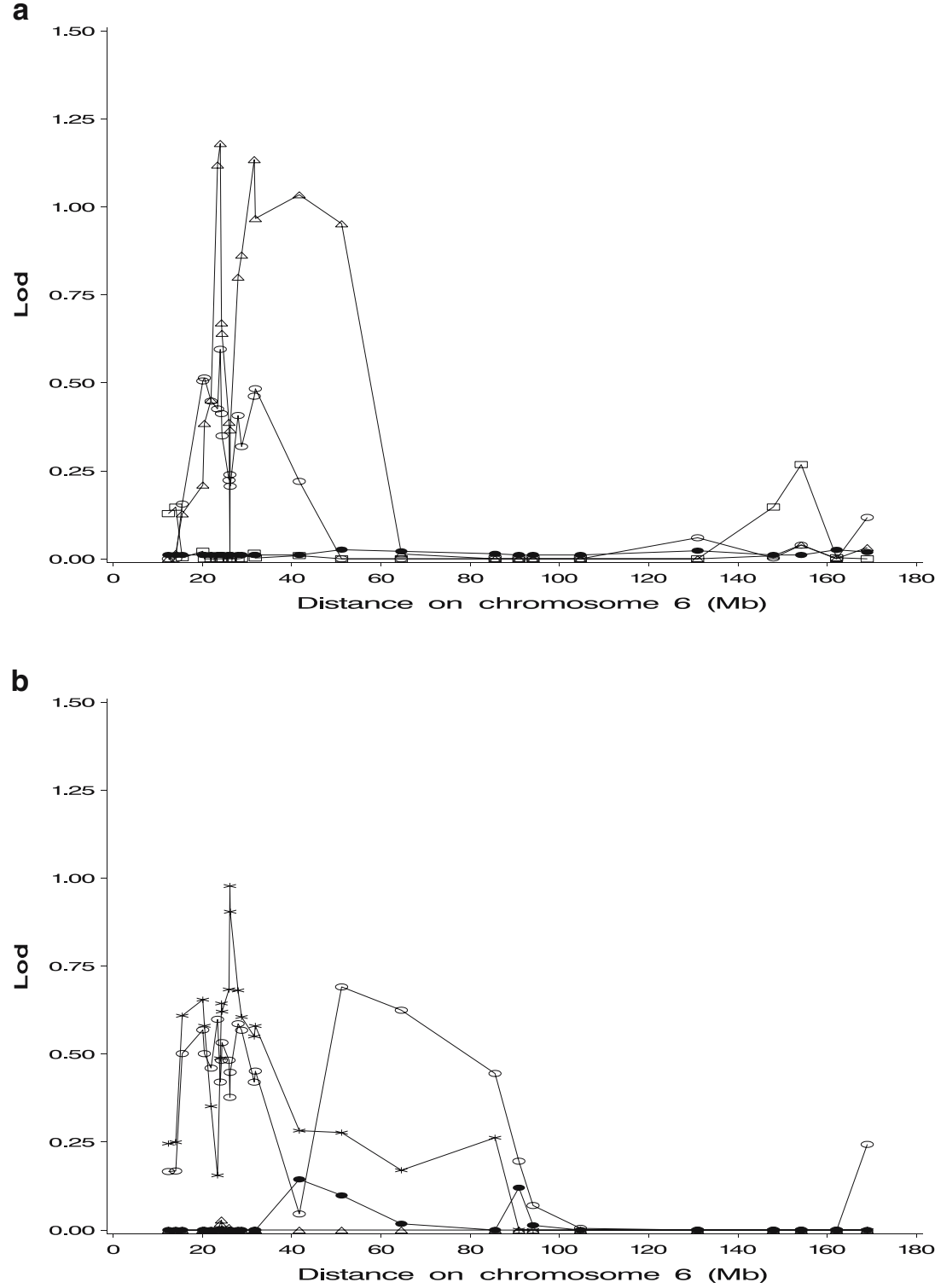

suggests that validations and replications from other independent studies should be strongly encouraged.

Interestingly, all nominal linkages especially found in whites were for the DI exercise training response. DI, $S_{\text {I }}$ and $\mathrm{AIR}_{\mathrm{g}}$ are non-independent traits. DI is a measure reflecting the balance between insulin secretion and insulin action on the disposition of glucose. In other words, DI is an index of insulin secretion adjusted for insulin sensitivity. Thus, finding stronger results for DI than for $\mathrm{AIR}_{\mathrm{g}}$ alone should not be surprising. The best replicated region across races for DI exercise training response was $6 \mathrm{p}$, with a lod score of 1.2 at D6S299 (24 Mb) in whites and of 1.0 at D6S2239 (26 Mb) in blacks. Previously, an interesting linkage in this region was found for baseline $S_{\mathrm{I}}$ (D6S2439, $27 \mathrm{Mb}$, lod score 1.7) in HERITAGE [4]. We propose that a quantitative trait locus in this region may harbour gene(s) that influence DI exercise training response with pleiotropic effects on baseline $S_{\mathrm{I}}$. Two previous studies reported quantitative trait loci at D6S276 (24 Mb, lod score 2.1) for type 2 diabetes in
Chinese Hans [34] and D6S273 (32 Mb, lod score 1.8) for fasting glucose in Pima Indians [21]. Candidate genes surrounding this locus include the TNF $\alpha(32 \mathrm{Mb}), B A T 2$ (32 Mb), HLA-DQB1 (33 Mb), PPARD (35 Mb) and $G L P 1 R(39 \mathrm{Mb})$ genes. TNF- $\alpha$ is an inflammatory cytokine with a wide range of anti-tumour and immune functions. Its role in the development of insulin resistance has been established [35]. The BAT2 gene is within the human major histocompatibility complex class III region. Its product is associated with the age at onset of type 1 diabetes, and possibly with the inflammatory process of pancreatic beta cell destruction during the development of type 1 diabetes. The HLA-DQB1 gene product specifies the autoimmune response against insulin-producing islet cells that leads to type 1 diabetes. Peroxisome proliferator-activated receptor (PPAR) $-\delta$ is ubiquitous, and belongs to one of the transcription factors of the superfamily of nuclear receptors. PPARs are major regulators of lipid and glucose metabolism and insulin sensitivity [36]. Glucagon-like peptide 1, a 
Fig. 3 Multipoint linkage analysis results on chromosome 7 for $S_{\mathrm{I}}$ (circles), $\mathrm{AIR}_{\mathrm{g}}$ (dots), DI (stars) and $S_{\mathrm{G}}$ (triangles) exercise training responses in whites (a) and on chromosome 19 for these phenotypes in blacks (b)
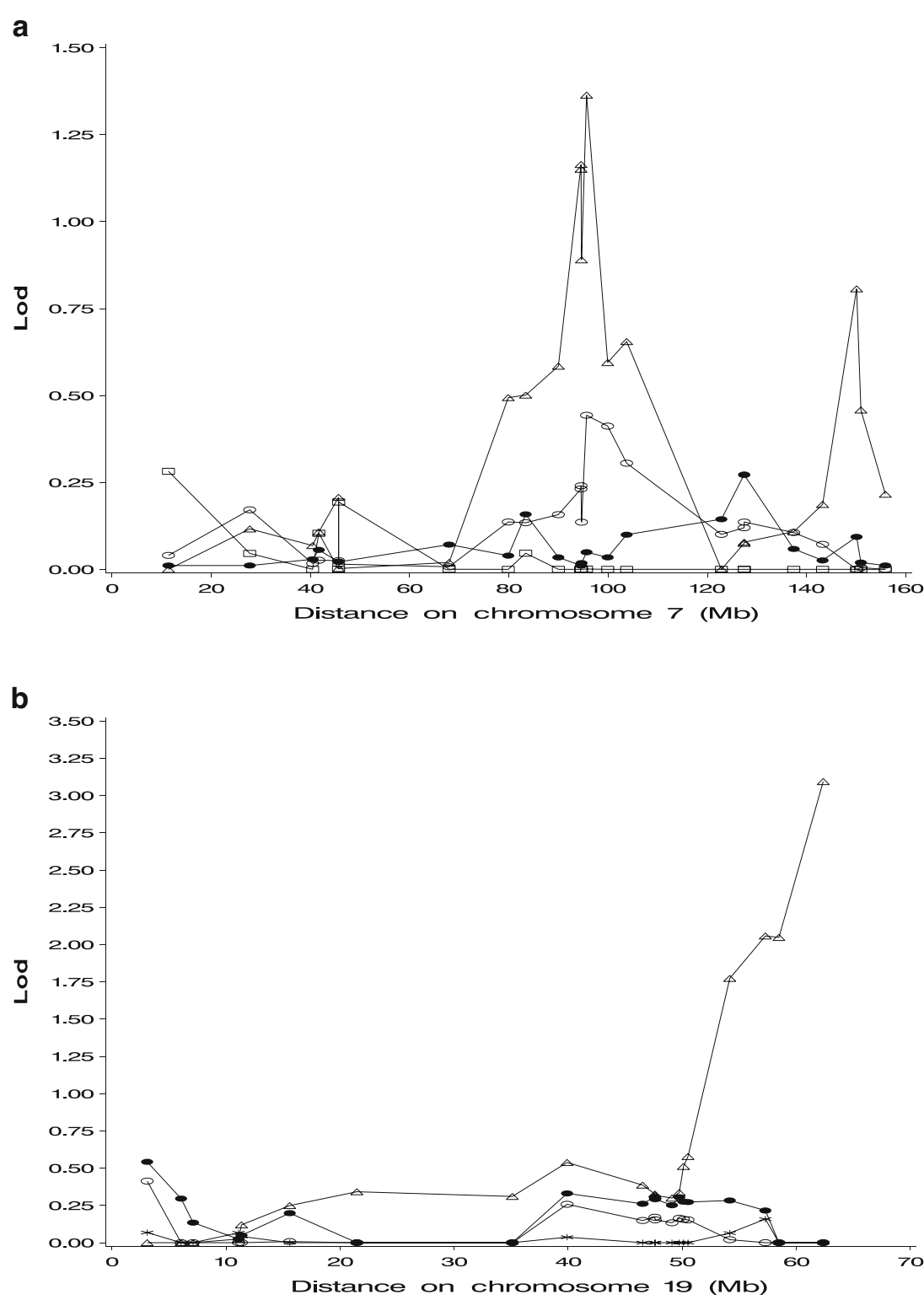

hormone derived from the preproglucagon molecule, and secreted by intestinal L cells, is the most potent stimulator of glucose-induced insulin secretion. It has potential for the treatment of type 2 diabetes because of its glucose-dependent insulinotropic and glucagonostatic properties [37]. Though the magnitude of the linkage signals on $6 \mathrm{p}$ is not striking, consistencies across whites and blacks and across several other cohorts at this locus warrant further studies.

Among the linkages on $1 p, 3 q, 7 q, 10 p$ and $12 q$ in whites and $1 \mathrm{p}, 2 \mathrm{p}, 10,12 \mathrm{q}, 13 \mathrm{q}, 15 \mathrm{q}, 18 \mathrm{q}, 20 \mathrm{q}$ and $22 \mathrm{q}$ in blacks, that on $7 \mathrm{q}$ at the PON1 gene locus D7S821 (95-96 Mb, highest lod score 1.4) for DI exercise training response in whites was supported by two previous findings. They include one at the PON1 gene locus (lod score 1.4) for fasting insulin exercise training response in HERITAGE whites [4], and one at D7S1799 (103 Mb, $Z$ score 1.9) for type 2 diabetes in Pima Indian sib pairs [38].

In conclusion, our genomic scans for glucose and insulin metabolism phenotypes in response to endurance exercise training yielded three quantitative trait loci of interest. A promising locus for $S_{\mathrm{G}}$ exercise training response was identified on 19q13 at the GYS1 locus; the GYS1 gene regulates glycogen storage in skeletal muscles. Two possible loci on $6 \mathrm{p}$ and $7 \mathrm{q}$ were captured for DI exercise training responses, accompanied by consistent findings for relevant traits across other studies.

Acknowledgements The HERITAGE Family Study was supported by the following grants from the National Heart, Lung, and Blood Institute: HL-45670 (to C. Bouchard, principal investigator), HL47323 (to A. S. Leon, principal investigator), HL-47317 (to D. C. Rao, principal investigator), HL-47327 (to J. S. Skinner, principal investigator) and HL-47321 (to J. H. Wilmore, principal investigator). Additional support was provided by the University of Minnesota's General Clinical Research Center (NIH Grant No. M01-RR000400) and the Henry L. Taylor Professorship in Exercise Science and Health Enhancement to A. S. Leon. C. Boucher is partially supported by the George A. Bray Chair in Nutrition. 


\section{References}

1. Nishida Y, Tokuyama K, Nagasaka S et al (2004) Effect of moderate exercise training on peripheral glucose effectiveness, insulin sensitivity, and endogenous glucose production in healthy humans estimated by a two-compartment-labeled minimal model. Diabetes 53:315-320

2. Boulé NG, Weisnagel SJ Lakka TA et al (2005) Effects of exercise training on measures of glucose and insulin metabolism derived from an intravenous glucose tolerance test. The HERITAGE Family Study. Diabetes Care 28:120-126

3. Bouchard C, Rankinen T (2001) Individual differences in response to regular physical activity. Med Sci Sports Exerc 33[6 Suppl]:S446-S451

4. An P, Hong Y, Weisnagel SJ et al (2003) Genomic scan of glucose and insulin metabolism phenotypes: the HERITAGE Family Study. Metabolism 52:246-253

5. Lakka TA, Rankinen T, Weisnagel SJ et al (2003) A quantitative trait locus on $7 \mathrm{q} 31$ for the changes in plasma insulin in response to exercise training: the HERITAGE Family Study. Diabetes $52: 1583-1587$

6. Boston RC, Stefanovski D, Moate PJ et al (2003) MINMOD Millennium: a computer program to calculate glucose effectiveness and insulin sensitivity from the frequently sampled intravenous glucose tolerance test. Diabetes Technol Ther 5:10031015

7. Bouchard C, Leon AS, Rao DC et al (1995) The HERITAGE family study. Aims, design, and measurement protocol. Med Sci Sports Exerc 27:721-729

8. Skinner JS, Wilmore KM, Krasnoff JB et al (2000) Adaptation to a standardized training program and changes in fitness in a large, heterogeneous population: the HERITAGE family study. Med Sci Sports Exerc 32:157-161

9. Walton C, Godsland IF, Proudler AJ et al (1992) Evaluation of four mathematical models of glucose and insulin dynamics with analysis of effects of age and obesity. Am J Physiol 262:E755E762

10. Desbuquois B, Aurbach GD (1971) Use of polyethylene glycol to separate free and antibody-bound peptide hormones in radioimmunoassays. J Clin Endocrinol Metab 33:732-738

11. Røder ME, Porte D Jr, Schwartz RS et al (1998) Disproportionately elevated proinsulin levels reflect the degree of impaired B cell secretory capacity in patients with noninsulin-dependent diabetes mellitus. J Clin Endocrinol Metab 83:604-608

12. Kahn SE, Leonetti DL, Prigeon RL et al (1995) Relationship of proinsulin and insulin with noninsulin-dependent diabetes mellitus and coronary heart disease in Japanese American men: impact of obesity - Clinical Research Center Study. J Clin Endocrinol Metab 80:1399-1406

13. Chagnon YC, Borecki IB, Pérusse L et al (2000) Genome-wide search for genes related to the fat-free body mass in the Quebec family study. Metabolism 49:203-207

14. Province MA, Rao DC (1995) A general purpose model and a computer program for combined segregation and path (SEGPATH): automatically creating computer program from symbolic language model specifications. Genet Epidemiol 12:203-219

15. Province MA, Rice T, Borecki IB (2003) A multivariate and multilocus variance components approach using structural relationships to assess quantitative trait linkage via SEGPATH. Genet Epidemiol 24:128-138

16. Kruglyak L, Lander ES (1995) Complete multipoint sib-pair analysis of qualitative and quantitative traits. Am J Hum Genet 57:439-454

17. Self SG, Liang KY (1987) Asymptotic properties of maximum likelihood estimators and likelihood ratio tests under nonstandard conditions. J Am Stat Assoc 82:605-610

18. Rao DC, Province MA (2000) The future of path analysis, segregation analysis, and combined models for genetic dissection of complex traits. Hum Hered 50:34-42

19. Loos RJ, Katzmarzyk PT, Rao DC et al (2003) Genome-wide linkage scan for the metabolic syndrome in the HERITAGE family study. J Clin Endocrinol Metab 88:5935-5943
20. Aouizerat BE, Allayee H, Cantor RM et al (1999) A genome scan for familial combined hyperlipidemia reveals evidence of linkage with a locus on chromosome 11. Am J Hum Genet 65:397-412

21. Pratley RE, Thompson DB, Prochazka M et al (1998) An autosomal genomic scan for loci linked to prediabetic phenotypes in Pima Indians. J Clin Invest 101:1757-1764

22. Panhuysen CI, Cupples LA, Wilson PW et al (2003) A genome scan for loci linked to quantitative insulin traits in persons without diabetes: the Framingham Offspring Study. Diabetologia 46:579-587

23. Watanabe RM, Ghosh S, Langefeld CD et al (2000) The Finland-United States investigation of non-insulin-dependent diabetes mellitus genetics (FUSION) study: II. An autosomal genome scan for diabetes-related quantitative-trait loci. Am J Hum Genet 67:1186-1200

24. Elbein SC, Hasstedt SJ (2002) Quantitative trait linkage analysis of lipid-related traits in familial type 2 diabetes: evidence for linkage of triglyceride levels to chromosome 19q. Diabetes 51:528-535

25. Mori Y, Otabe S, Dina C et al (2002) Genome-wide search for type 2 diabetes in Japanese affected sib-pairs confirms susceptibility genes on $3 \mathrm{q}, 15 \mathrm{q}$, and $20 \mathrm{q}$ and identifies two new candidate loci on $7 \mathrm{p}$ and $11 \mathrm{p}$. Diabetes 51:1247-1255

26. van Tilburg JH, Sandkuijl LA, Strengman E et al (2003) A genome-wide scan in type 2 diabetes mellitus provides independent replication of a susceptibility locus on $18 \mathrm{p} 11$ and suggests the existence of novel loci on $2 \mathrm{q} 12$ and $19 \mathrm{q} 13$. J Clin Endocrinol Metab 88:2223-2230

27. Best JD, Kahn SE, Ader M et al (1996) Role of glucose effectiveness in the determination of glucose tolerance. Diabetes Care 19:1018-1030

28. Henriksen JE, Alford F, Handberg A et al (1994) Increased glucose effectiveness in normoglycemic but insulin-resistant relatives of patients with non-insulin-dependent diabetes mellitus. A novel compensatory mechanism. J Clin Invest 94:11961204

29. Vaag A, Henriksen JE, Beck-Nielsen H (1992) Decreased insulin activation of glycogen synthase in skeletal muscles in young nonobese Caucasian first-degree relatives of patients with noninsulin-dependent diabetes mellitus. J Clin Invest 89:782-788

30. Groop LC, Kankuri M, Schalin-Jantti C et al (1993) Association between polymorphism of the glycogen synthase gene and noninsulin-dependent diabetes mellitus. N Engl J Med 328:10-14

31. Motoyama K, Emoto M, Tahara H et al (2003) Association of muscle glycogen synthase polymorphism with insulin resistance in type 2 diabetic patients. Metabolism 52:895-899

32. Huang X, Vaag A, Hansson M et al (2000) Impaired insulinstimulated expression of the glycogen synthase gene in skeletal muscle of type 2 diabetic patients is acquired rather than inherited. J Clin Endocrinol 85:1584-1590

33. Chakravarthy MV, Booth FW (2004) Eating, exercise, and 'thrifty' genotypes: connecting the dots toward an evolutionary understanding of modern chronic diseases. J Appl Physiol 96:310

34. Luo TH, Zhao Y, Li G et al (2001) A genome-wide search for type II diabetes susceptibility genes in Chinese Hans. Diabetologia 44:501-506

35. Borst SE (2004) The role of TNF- $\alpha$ in insulin resistance. Endocrine 23:177-182

36. Ferré $\mathrm{P}$ (2004) The biology of peroxisome proliferator-activated receptors: relationship with lipid metabolism and insulin sensitivity. Diabetes 53 [Suppl 1]:S43-S50

37. Meier JJ, Nauck MA (2004) The potential role of glucagon-like peptide 1 in diabetes. Curr Opin Investig Drugs 5:402-410

38. Hanson RL, Ehm MG, Pettitt DJ et al (1998) An autosomal genomic scan for loci linked to type II diabetes mellitus and body-mass index in Pima Indians. Am J Hum Genet 63:11301138 